\title{
KLINIKINIS ATVEJIS: HIPERLIPIDEMINIS PANKREATITAS
}

\author{
Armantas Gintautas, Tomas Janušonis, Renata Paškevičiūtè \\ Klaipédos universitetine ligonine, Anesteziologijos ir reanimatologijos klinika
}

Raktažodžiai: hiperlipidemija, hipertrigliceridemija, pankreatitas, cukrinis diabetas, diabetinè ketoacidozè, plazmaferezè.

\section{Santrauka}

Hiperlipideminis pankreatitas (HP) diagnozuojamas, kai yra labai didelis trigliceridų (TG) kiekis kraujyje ir nenustatoma kitų priežasčių, galëjusių sukelti ūmini pankreatitą (ŪP). Mes pristatome klinikinị atveji, kai $39 \mathrm{~m}$. moteriai buvo diagnozuotas HP kartu su diabetine ketoacidoze (DKA) ir 2 tipo cukriniu diabetu (CD). Moteriai CD diagnozuotas pirmą kartą gyvenime - DKA buvo pradiné diabeto klinikinè išraiška. Atlikti tyrimai patvirtino UিP diagnozę, taip pat nustatyta sunki hipertrigliceridemija (HTG) - 20,69 $\mathrm{mmol} / 1$. Taikant ịprastas ŪP ir kompleksines HP gydymo priemones (plazmaferezę, pastovią insulino ir heparino infuziją) TG kiekis kraujyje per dvi dienas sumažejo iki optimalaus kiekio. Bendra ligonès būklè gydymosi intensyviosios terapijos skyriuje metu buvo stabili, nors infekcinių komplikacijų išvengti nepavyko. Po 23 dienų moteris išrašyta ị namus (rekomenduotas tolimesnis priežiūros planas specialistų kontrolëje ir pabrěžta rizikos veiksnių valdymo svarba).

\section{İvadas}

ŪP yra gyvybei grèsminga ūmi kasos uždegiminè būklè. ŪP paplitimas pasaulyje didejja ir jo dažnis Vakarų šalių populiacijoje yra 40/100000 [1-2]. Bendras mirštamumas nuo ŪP yra apie 5 proc. [3]. Remiantis tarptautinèmis gairèmis, diagnozė patvirtinama, jei yra bent 2 iš 3 kriterijų [4-7]: nuolatinis skausmas epigastriumo srityje (nuo vidutinio iki stipraus intensyvumo, paprastai plintantis ị nugarą); amilazès ir lipazès aktyvumo padidejjimas kraujyje daugiau kaip 3 kartus; kasos parenchimos struktūriniai pokyčiai, patvirtinti diagnostiniais tyrimais (pilvo kompiuterine tomografija, branduoliniu magnetiniu rezonansu ar ultragarsu). Dažniausios ŪP priežastys yra tulžies pūslès ir latakų akmenligè bei alkoholio vartojimas (apie 80 proc. visų ŪP atvejų). HTG, remiantis literatūros duomenimis, yra trečia priežastis ir su- daro apie 7-10 proc., o gestacinio diabeto atveju iki 50 proc. visų ŪP atvejų [8-10]. HTG gali būti pirminè (šeiminė) ar antrinè dèl piktnaudžiavimo alkoholiu, $\mathrm{CD}$, vartojamų vaistų [11]. Turintys antsvorio ir nutukę pacientai yra dažniau linkę sirgti ŪP, ir tam įtakos gali turèti atsparumas insulinui, hiperglikemija ir HTG [12]. HP diagnozuojamas, kai, nesant kitų priežasčių, TG kiekis kraujyje yra daugiau kaip 11,322,6 mmol/1 (1000-2000 mg/dL) [13-14]. Svarbu atkreipti dèmesi, kad pankreatito (sukelto ne dèl HTG) atveju galimas bendro cholesterolio kiekio kraujyje padidejjimas, kuris neturètų būti sumaišytas su itin dideliu TG kiekiu HP metu [11].

\section{Klinikinis atvejis}

39 metų moteris, turinti nedidelị antsvorị (kūno masès indeksas $25 \mathrm{~kg} / \mathrm{m}^{2}$ ), kreipèsi ị universitetinę ligoninę dèl tos pačios dienos ryte prasidejusio pilvo skausmo epigastriumo srityje, pykinimo, vèmimo, bendro silpnumo. Tokie nusiskundimai atsirado pirmą kartą. Ligonè vartojo drotaveriną, tačiau poveikio nebuvo. Pacientė serga pirmine hipertenzija, CD neigia. Apžiūros metu: hemodinamika stabili (širdies susitraukimų dažnis 80 kartų per minutę, arterinis kraujospūdis $120 / 70 \mathrm{mmHg}$ ), spontaninis alsavimas pakankamas, pilvas išpūstas, skausmingas visame plote, labiausiai - bambos srityje, be pilvaplèvės dirginimo simptomų. Iškvepiamame ore jautėsi acetono kvapas. Buvo įtartas ŪP, ligonè hospitalizuota ị gastroenterologijos skyrių. Atlikta fibrogastroduodenoskopija, išvada: tulžies refliukso požymiai, eriteminè gastropatija, eriteminis duadenitas (galima reakcija dèl kasos patologijos). Kraujo tyrimai: padidejęs amilazès (672 U/1) ir lipazès (824 U/l) aktyvumas, hiperglikemija (17,28 mmol/l), CRB 415,79 mg/l, ALT, AST ir kreatinino kiekis neišmatuojami dèl ryškios hiperlipemijos $(++++)$. Šlapimo tyrimas: gliukozė šlapime $28 \mathrm{mmol} / \mathrm{l}$, ketonai šlapime 5 $\mathrm{mmol} / 1(++)$. Dèl stiprejjančiu pilvo skausmų ir sunkejjančios bendros būklès pirmą gydymosi ligoninèje parą pacientè perkelta ị intensyviosios terapijos skyrių. Atliktuose tyrimuose (1, 2 lentelès): metabolinè acidozè, bendro cholesterolio kiekis $>18,26 \mathrm{mmol} / 1, \mathrm{TG}>20,69 \mathrm{mmol} / \mathrm{l}$, ryškiai padidejję uždegimo žymenys (prokalcitonino, CRB kiekis), pilvo srities kompiuterinès tomografijos tyrime - kasos parenchima 
kontrastuojasi gana homogeniškai, latakas neišplèstas, aplinkiniuose kasos audiniuose skysčio sankaupos be aiškiu ribų. Pacientei pasireiškej kvejpavimo funkcijos nepakankamumas, buvo pradèta taikyti dirbtinè plaučių ventiliacija. Atliktas krūtinès ląstos kompiuterinès tomografijos tyrimas, diagnozuotas plaučių uždegimas, pasèlyje iš endotrachèjinio aspirato išaugo Acinetobacter baumanii (jautrus tik kolistinui) ir Staphylococcus aureus (jautrus oksacilinui). Taikytas gydymas: infuzoterapija, sedacija, analgetikai, enterinis maitinimas, albuminas, antibiotikoterapija, eritrocitu masès transfuzijos, elektrolitų disbalanso korekcija. Hiperlipidemijai gydyti atliktos dvi plazmaferezès. Kraujo plazma plazmaferezès metu buvo ryškiai lipeminè (1 paveikslas). Taip pat skirtas insulinas (palaikant optimalų gliukozès kiekị kraujyje) ir heparinas (stebint krešumo rodiklius) automatine švirkštine pompa. Gydymo eigoje pacientès būklè stabilizavosi ir pradėjo gerèti: sumažèjo TG kiekis, uždegimo žymenų kiekis. Koreguota pasireiškusi anemija, hipokalemija, hipernatremija, hiperosomoliariškumas, kontroliuota glikemija (insulinas pradètas leisti po oda). Normalizavusis plaučių funkcijai pacientė atjungta nuo dirbtinès plaučių ventiliacijos (ji truko iš viso 13 dienų). Tolesniam gydymui perkelta ị endokrinologijos skyrių ir, esant visiškai stabiliai būklei, išleista ị namus. Rekomenduotas gydymas: hipolipideminè dieta, lipidų kiekị kraujyje mažinantys vaistai, insulinas (bendra paros dozè $24 \mathrm{VV}$ ), genetiniai tyrimai dèl šeiminès hiperlipidemijos. Galutinè diagnozè: ūminis hiperlipideminis pankreatitas. Gryna hipertriacilglicerolemija.

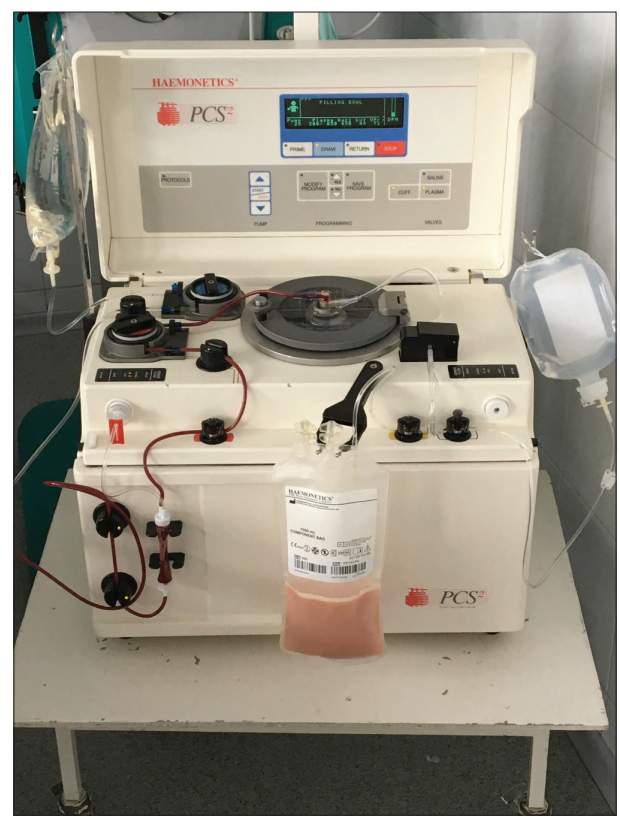

1 paveikslas. Kraujo plazma plazmaferezès metu
Acinetobacter baumanii ir Staphylococcus aureus sukelta pneumonija. Ūminis kvépavimo funkcijos nepakankamumas. Cukrinis diabetas, 2 tipo, dekompensuotas. Acidozè. Hipokalemija. Hiperosmoliariškumas ir hipernatremija. Antrinè anemija. Paciente iš viso ligoninëje buvo gydoma 23 dienas, intensyviosios terapijos skyriuje - 19 dienų.

\section{Diskusija}

HTG sudaro 7-10 proc. iš visų ŪP priežasčių, tuo tarpu ŪP dažnis tarp pacientų, kuriems yra HTG, yra 14 proc. [15-16]. HTG diagnozuojama, kai TG kiekis kraujyje yra $>1,69 \mathrm{mmol} / \mathrm{l}(150 \mathrm{mg} / \mathrm{dL})$, sunki - daugiau kaip 22,6 mmol/1 $(2000 \mathrm{mg} / \mathrm{dL})$ [19]. Vien pirminè HTG (šeiminè, genetiškai nustatyta) yra reta HP priežastis [17-18]. HP savarankiškai gali sukelti I dislipidemijos tipas (̌̌eiminè chilomikronemija; paveldima autosominiu recesyviniu būdu) pagal Fredrickson'o klasifikaciją (HTG - dèl lipoproteinlipazès ir apolipoproteino C-II defekto), kuris dažniausiai diagnozuojamas ankstyvoje vaikysteje ir yra labai retas (1/1000000). Dislipidemijos IV tipas (šeiminè HTG; paveldima autosominiu dominantiniu būdu), kuris yra dažniausiais iš visų šeiminių dislipidemijų (1/100), vyresniame amžiuje gali manifestuoti sunkia HTG ar ŪP, kai kartu yra bent vienas antrinę HTG sukeliantis priežastinis veiksnys $[9,14]$. Antrinę HTG sukeliančios priežastys yra alkoholio vartojimas, nutukimas, nekontroliuojamas $\mathrm{CD}$, hipotirozè, něštumas, vartojami vais-

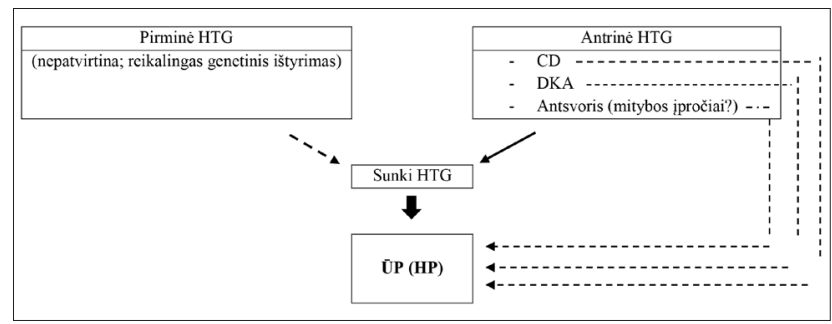

2 paveikslas. Klinikinio atvejo - ŪP $(\mathrm{HP})$ galimas patogenezinis mechanizmas

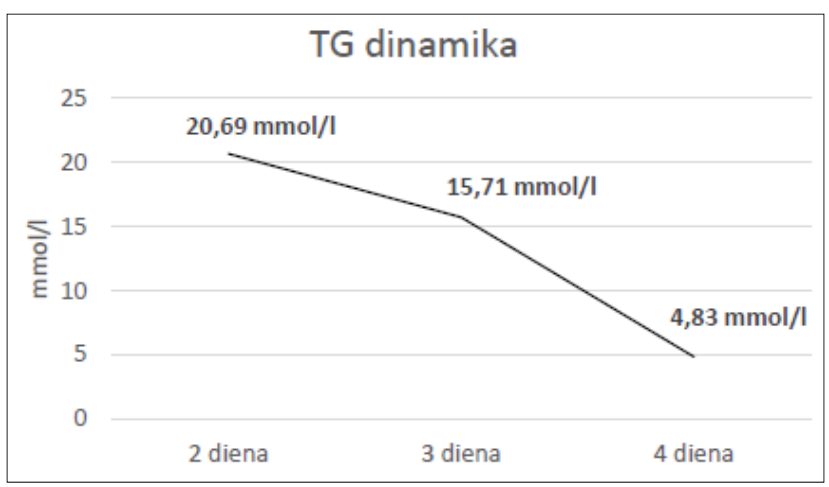

3 paveikslas. TG dinamika kraujyje 2-4 gydymosi dieną 
1 lentelè. Laboratorinių kraujo tyrimų rezultatai (nuo guldymo pradžios iki gydymo intensyviosios terapijos skyriuje pabaigos)

\begin{tabular}{|c|c|c|c|c|c|c|c|c|c|c|c|c|c|}
\hline \multirow{2}{*}{ Tyrimai } & \multicolumn{13}{|c|}{ Gydymosi dienos (D) nuo guldymo pradžios iki gydymo intensyviosios terapijos skyriuje pabaigos } \\
\hline & D1 & D2 & D3 & D4 & D5 & D6 & D7 & D9 & D11 & D13 & D14 & D17 & D20 \\
\hline $\mathrm{Hb}(\mathrm{g} / \mathrm{l})$ & 174 & 122 & 91 & 80 & 78 & 106 & & & & 95 & & & \\
\hline Het (\%) & 38,8 & 30,2 & 27,9 & 24,5 & 22,1 & 30,3 & & & & & & & \\
\hline Trombocitai $\left(\times 10^{9} / \mathrm{l}\right)$ & 322 & 239 & & & 197 & & & & & 208 & & & \\
\hline Leukocitai (x109/1) & 10,38 & 8,37 & & & 10,44 & 11,80 & & & & 9,47 & & & \\
\hline Neutrofilai (x109/l) & 7,14 & 7,24 & & & & & & & & 6,8 & & & \\
\hline $\mathrm{K}(\mathrm{mmol} / \mathrm{l})$ & & 3,8 & 4,5 & 3,6 & 3,6 & 4,0 & 3,4 & 4,0 & 5,2 & 3,8 & 4,2 & 3,8 & \\
\hline $\mathrm{Na}(\mathrm{mmol} / \mathrm{l})$ & & 139 & 148 & 146 & 149 & 151 & 151 & 149 & 149 & 143 & 138 & 138 & \\
\hline $\mathrm{Ca}(\mathrm{mmol} / \mathrm{l})$ & & 2,05 & 2,12 & 2,14 & 2,23 & 2,43 & 2,31 & 2,28 & & & & & \\
\hline Urea (mmol/l) & $<7,0$ & 2,6 & 2,4 & 2,5 & & & 4,9 & 4,6 & & & & & \\
\hline Kreatininas $(\mu \mathrm{mol} / \mathrm{l})$ & $<90$ & 74,0 & 57,6 & 57,8 & & & 65,0 & 85,3 & 108,2 & & & & 75,3 \\
\hline ALT (U/I) & $<60$ & $<30$ & 15 & 17 & & & & 49 & & & & & \\
\hline AST (U/I) & $<30$ & 20 & 32 & 27 & & & & 32 & & & & & \\
\hline LDH (U/l) & 198 & & & & & & & & & & & & \\
\hline Albuminas (g/l) & & 35 & & & & & 26 & 34 & & & & 34 & \\
\hline CRB (mg/l) & 415,79 & 405,57 & 271,69 & 256,19 & & & 166,72 & 255,59 & 229,20 & & 116,28 & 44,94 & 19,42 \\
\hline PCT (ng/ml) & & 0,924 & 0,543 & 0,362 & 0,283 & 0,191 & 0,161 & 0,251 & 0,240 & & 0,469 & 0,265 & \\
\hline Alfa amilazė (U/l) & 672 & 407 & 105 & 63 & & & & 22 & & & & & \\
\hline Lipazė (U/I) & 824 & 765 & 212 & 128 & & & & 91 & & & & & \\
\hline $\begin{array}{l}\text { Bendras cholesterolis } \\
(\mathrm{mmol} / \mathrm{l})\end{array}$ & & 18,26 & 15,16 & 14,07 & & & 10,37 & 6,78 & & 4,98 & & 5,87 & \\
\hline DTL (mmol/l) & & 0,52 & & & & & & 0,52 & & 0,69 & & 0,77 & \\
\hline MTL (mmol/l) & & 2,0 & & & & & & 3,81 & & & 3,37 & 3,65 & \\
\hline Trigliceridai (mmol/l) & & 20,69 & 15,71 & 4,83 & & & 4,61 & 4,57 & & & 3,02 & 4,48 & \\
\hline Gliukozė (mmol/l) & 17,28 & $\begin{array}{l}9,25- \\
10,55\end{array}$ & $\begin{array}{l}8,01- \\
10,05\end{array}$ & $\begin{array}{l}4,19- \\
11,80\end{array}$ & $\begin{array}{l}6,96- \\
10,37\end{array}$ & $\begin{array}{l}7,67- \\
10,24\end{array}$ & $\begin{array}{l}7,24- \\
10,07\end{array}$ & $\begin{array}{l}8,86- \\
12,54\end{array}$ & $\begin{array}{l}4,13- \\
9,60\end{array}$ & $\begin{array}{l}5,11- \\
7,42\end{array}$ & $\begin{array}{l}6,13- \\
8,99\end{array}$ & $\begin{array}{c}5,50- \\
8,22\end{array}$ & $\begin{array}{l}5,79- \\
7,79\end{array}$ \\
\hline
\end{tabular}

2 lentelè. Kraujo dujų tyrimų rezultatai

\begin{tabular}{|l|l|l|l|l|l|l|l|}
\hline \multirow{2}{*}{ Tyrimai } & \multicolumn{6}{|c|}{$\begin{array}{c}\text { Gydymosi dienos (D) nuo guldymo pradžios } \\
\text { (intensyviosios terapijos skyriuje) }\end{array}$} \\
\cline { 2 - 8 } & $\mathrm{D} 2$ & $\mathrm{D} 3$ & $\mathrm{D} 4$ & $\mathrm{D} 5$ & $\mathrm{D} 6$ & $\mathrm{D} 7$ & $\mathrm{D} 8$ \\
\hline $\mathbf{p H}$ & 7,050 & 7,202 & 7,436 & 7,470 & 7,595 & 7,595 & 7,469 \\
\hline $\mathbf{p O}_{\mathbf{2}} \mathbf{( m m H g )}$ & 48,6 & 183 & 131 & 119,3 & 109 & 123 & 125 \\
\hline $\mathbf{p C O}_{\mathbf{2}} \mathbf{( m m H g )}$ & 17,7 & 28,1 & 35,6 & 40,1 & 34,7 & 35,7 & 41,2 \\
\hline BE (mmol/l) & $-25,6$ & $-16,9$ & $-0,3$ & 5,5 & 12,2 & 13,0 & 13,5 \\
\hline $\begin{array}{l}\text { Osmoliariškumas } \\
\text { (mosm/kg) }\end{array}$ & 294,1 & 298,3 & 294,9 & 306,6 & 305,3 & 304,8 & 299,1 \\
\hline
\end{tabular}


tai (beta adrenoblokatoriai, propofolis, tiazidiniai diuretikai, priešvirusiniai vaistai, estrogeniniai preparatai, klomifenas, olanzapinas, mirtazapinas, valproinè rūgštis) $[14,16,19$ 21]. Kaip nurodo kai kurie autoriai, dekompensuotas CD yra dažniausia antrinès HTG priežastis. 1 tipo $C D$ atveju lipoproteinlipazė mažiau TG konvertuoja į riebiasias rūgštis dèl insulino trūkumo, ir dèl to galima HTG. 2 tipo CD metu prie HTG patogenezès prisideda ir atsparumas insulinui, dèl ko didejja TG gamyba ir sumažèja jų klirensas. Diabetinè ketoacidozė gali būti savarankiškas HTG rizikos veiksnys [14].

Slenkstinis TG kiekis kraujyje, kuris sukelia ŪP, nèra tikslai žinomas, bet galioja bendra taisyklè ,kuo didesnis TG kiekis, tuo didesnè ŪP rizika“ [15]. Dažniausiai literatūroje HP apibrěžiamas, kai TG kiekis kraujyje yra daugiau kaip $11,3 \mathrm{mmol} / 1$ (1000 mg/dL). Remiantis sistemine apžvalga, i kurią įtraukti 34 tyrimai su 1340 pacientais, kuriems diagnozuotas HP, vidutinis TG kiekis kraujyje siekè 29,99 $\mathrm{mmol} / \mathrm{l}(2654 \mathrm{mg} / \mathrm{dl})$. Šie rezultatai sustiprina prielaidą, kad slenkstinè HTG, kuri sukelia HP yra $>11,3 \mathrm{mmol} / 1$, tuo tarpu nedidelis TG padidèjimas (iki 3,3-4,5 mmol/l) yra dažnai nustatomas esant ŪP dèl kitų priežasčių [16]. ŪP dažnis esant $\mathrm{TG}>11,3 \mathrm{mmol} / \mathrm{l}$ yra 5 proc., kai $>22,6 \mathrm{mmol} / 1$ - nuo 10 iki 20 proc. [19].

Esant HTG formuojasi chilomikronai ir kraujo serumo spalva tampa panaši ị pieno [14]. Lipeminis kraujo mėginys gali padèti ịtarti HP pacientams, kurie ị skubios pagalbos skyrių kreipiasi skųsdamiesi pilvo skausmu (autorių duomenimis, maždaug pusei pacientų atvykus ị gydymo įstaigą su HP imant kraujo mèginį randamas ị ,pieną panašus" kraujas) [22]. Reikia pabrèžti, kad vertinant lipidogramą pankreatito (sukelto ne dèl HTG) atveju, galimas bendro cholesterolio kiekio kraujyje padidèjimas, kuris neturètų būti sumaišytas su itin dideliu TG kiekiu HP metu. Kai yra sunki HTG, taip pat galimos tyrimų paklaidos: tariamai normalūs ar maži elektrolitų kiekiai, mažas gliukozės kiekis (aprašyti keli atvejai, kai DKA gydymas pradètas per vèlai dèl pseudonormoglikemijos), santykinai mažas amilazès aktyvumas kraujyje ir šlapime (reikia skaičiuoti amilazès/kreatinino santykį, kuris yra tikslesnis rodmuo esant HTG) [23]. Nors nėra patvirtintų rekomendacijų dèl lipazès aktyvumo rodmens didesnès reikšmės esant HP, kai kurie autoriai nurodo, kad lipazès aktyvumas yra specifiškesnis ir jautresnis rodmuo negu amilazès aktyvumas ŪP metu [14].

Gali kilti klausimas, kurio pankreatito eiga yra sunkesnè: HP ar ŪP sukelto dèl kitų priežasčių? Deja, šiuo metu trūksta patikimų įrodymų, tačiau, remiantis turimais duomenimis, galima daryti išvadą, kad HTG, lyginant su kitomis priežastimis, sukelia sunkesnès eigos ŪP, taip pat tikètinas didesnis inkstų funkcijos nepakankamumo, šoko, infekcijų ir mirties dažnis [24]. Mūsų gydytos pacientes mirties rizika apskaičiuota pagal APACHE II ir RANSON skales: atitinkamai siekè 12 proc. ir 15 proc. Ligonès bendra būklè gydymosi intensyviosios terapijos skyriuje buvo stabili (be šoko, dauginio organų pažeidimo), nors infekcinių komplikacijų (plaučiu uždegimo su kvėpavimo funkcijos nepakankamumu) išvengti nepavyko.

HP patogenezè nèra tiksliai žinoma. Labiausiai pripažinta teorija, teigianti, kad pertekliniai TG yra hidrolizuojami pankreatinès lipazès ir taip susidaro didelè laisvųų riebiųjų rūgščių koncentracija. Kai viršijama plazmos albumino geba sujungti riebiąsias rūgštis, jos sudaro miceles, kurios, veikdamos kaip detergentai, atakuoja trombocitus, kraujagyslių endotelį, kasos egzokrinines ląsteles. Dẻl kapiliarų obstrukcijos susidaro lokali išemija, acidozė (kuri dar labiau padidina riebiưjų rūgščių toksiškumą), aktyvuojama uždegiminè kaskada. Kasos kapiliarų išemija galimai sukeliama

3 lentelė. Intensyviojoje terapijoje dažnai naudojami vaistai, kurių reiktų vengti ar vartoti atsargiai esant HP (HP kartu su CD) metu

* Parengta remiantis vaistiniu preparaty charakteristikomis

\begin{tabular}{|c|c|c|c|}
\hline \multirow[b]{2}{*}{ Vaistas } & HP & HP kartu su CD & \multirow[b]{2}{*}{ Rekomendacija } \\
\hline & $\begin{array}{c}\text { Specialūs ịspèjimai / Nepa- } \\
\text { geidaujamas poveikis }\end{array}$ & $\begin{array}{c}\text { Kontraindikacijos/ Nepagei- } \\
\text { daujamas poveikis }\end{array}$ & \\
\hline Propofolis & \multicolumn{2}{|c|}{$\begin{array}{l}\text { Ypač atsargiai reikia vartoti pacientams, kurių riebalų metabolizmas } \\
\text { sutrikęs. Pacientą pradejjus gydyti intensyviosios terapijos skyriuje, } \\
\text { po } 3 \text { parų reikia pradèti sekti lipidų koncentraciją }\end{array}$} & Sedacijai rinktis kitus vaistus \\
\hline $\begin{array}{l}\text { Beta adrenobloka- } \\
\text { toriai }\end{array}$ & $\begin{array}{l}\text { Lipidų metabolizmo pakitimai } \\
\text { (trigliceridų ir cholesterolio } \\
\text { koncentracijų pokyčiai krau- } \\
\text { jyje) }\end{array}$ & $\begin{array}{l}\text { Negali būti vartojami esant meta- } \\
\text { bolinei acidozei CD metu (DKA) }\end{array}$ & $\begin{array}{l}\text { Rinktis kardioselektyvius prepa- } \\
\text { ratus, jei reikia juos skirti; rinktis } \\
\text { kitus vaistus jei ŪP yra kartu su } \\
\text { CD ir DKA }\end{array}$ \\
\hline $\begin{array}{l}\text { Atipiniai neurolep- } \\
\text { tikai (ypač olanza- } \\
\text { pinas) }\end{array}$ & $\begin{array}{l}\text { Lipidų metabolizmo pakitimai } \\
\text { (trigliceridų ir cholesterolio } \\
\text { koncentracijų pokyčiai krau- } \\
\text { jyje) }\end{array}$ & $\begin{array}{l}\text { Dėl padidèjusio atsparumo insu- } \\
\text { linui gali didinti gliukozès kiekị } \\
\text { kraujyje }\end{array}$ & $\begin{array}{l}\text { Rinktis tipinius neuroleptikus } \\
\text { (pvz. haloperidoli) }\end{array}$ \\
\hline
\end{tabular}


ir/ar dèl padidejusio chilomikronų kiekio ir didesnio kraujo klampumo [14]. Tai patvirtina keli eksperimentiniai tyrimai, kurių metu laisvąsias riebiąsias rūgštis švirkšiant ị izoliuotą šuns kasos audinį sukelta edema ir hemoragijos [16, 25-26]. Publikuoti tyrimo duomenys, kurio autoriai kinų populiacijoje nustate specifiškus genus, kurių mutacija (cistinès fibrozės transmembraninio laidumo reguliatoriaus baltymo geno mutacija ir tumoro nekrozès faktoriaus aktyvatoriaus polimorfizmas) yra nepriklausomas HP rizikos veiksnys. Tad, galima daryti išvadą, kad reikalingi tolimesni tyrimai siekiant išsiaiškinti HP patogenezinius mechanizmus ir juos pritaikant gydymui ateityje [27].

Mūsų pristatomame atvejyje pacientè, tikètina, turejjo mišrų patogenezinį mechanizmą, sukèlusị pankreatitą (2 paveikslas). 2 tipo CD (nustatytas pirmą kartą gyvenime), DKA ir HTG - trys rizikos veiksniai, iš kurių kiekvienas atskirai gali sukelti ŪP. Mūsų pacientè neigè CD. DKA šiai pacientei buvo pradinè CD klinikine išraiška. Nors DKA daug dažniau pasitaiko sergantiesiems 1 tipo CD (apie 60-70 proc. visų DKA atvejų), sergant 2 tipo CD tai yra taip pat gana dažna komplikacija, ir, kai kurių autorių duomenimis, 27 proc. pacientų, kuriems yra DKA, yra naujai diagnozuojamas diabetas [28]. 2 tipo CD metu dèl sumažèjusio insulino kiekio ar atsparumo insulinui TG kiekis padidejja dèl kelių mechanizmų: sumažejusio lipolizès slopinimo adipocituose ir padidejusio laisvųjų riebiujų rūgščių srauto ị kepenis; padidejusios labai mažo tankio lipoproteinų (LMTL) ir TG gamybos kepenyse; sumažejusio lipoproteinlipazès aktyvumo ir dèl to sumažejejusios LMTL konversijos ị mažo tankio lipoproteinus (MTL); pakitusios LMTL struktūros dèl padidèjusio cholesterolio esterio pernešimo baltymo aktyvumo. Mūsų atveju CD kartu su DKA patvirtina insulino deficitą pacientei, nes DKA pasižymi absoliučiu ar reliatyviu insulino deficitu ir apibūdinama šia triada: hiperglikemija, metabolinè acidozè, ketonemija. DKA nutukusiems 2 tipo CD sergantiems pacientams dažnai pasireiškia kartu HTG dèl minèto insulino deficito ir antsvorio. Klinikinejje praktikoje, remiantis pranešimų duomenimis, gydant DKA svarbu atminti, kad: DKA, ypač esant ryškiai acidozei, dažnai pasireiškia kartu su pilvo skausmu be chirurginès patologijos; tačiau apie 15 proc. pacientų, kuriems yra DKA, diagnozuojamas ÜP, ypač kai DKA yra kartu su HTG (TG kiekis gali būti santykinai nedidelis), nes kaip manoma, jie yra vieni iš svarbiausių kasos uždegimo rizikos veiksnių (po alkoholio ir tulžies akmenų) [21]. Galima daryti prielaidą, kad šiuo atveju komplikuotas $\mathrm{CD}$ yra pagrindinè priežastis, sukèlusi antrinę HTG (kiti svarbūs rizikos veiksniai, išskyrus nedideli antsvorį, nebuvo nustatyti). Apie pirminę HTG duomenų neturejome (lipidograma pacientei anksčiau nebuvo daryta, šeiminę anamnezę ji neigia). Mūsų pacientei nustatyta sunki
HTG, tikètina, sukelta ir kartu esamos šeiminès HTG. Jai patvirtinti reikalinga atlikti genetinius tyrimus (išrašant i namus tai buvo numatyta tolimesniame priežiūros plane).

Nèra tiksliai apibrezžto HP gydymo. Literatūroje (daugiausia remiantis aprašytais klinikiniais atvejais) HP gydymas apima įprastas ŪP terapines priemones kartu su insulino ir/ar heparino infuzija, plazmafereze ar hemodiafiltracija, siekiant kaip įmanoma greičiau sumažinti TG kiekị kraujyje [14, 16, 30]. Insulinas (tiesioginis poveikis) ir heparinas (atpalaiduoja lipoproteinlipazę iš kraujagyslių endotelio ląstelių) padidina lipoproteinlipazès aktyvumą ir taip padeda normalizuoti padidejusị TG kiekị. Insulinas, remiantis turimais ịrodymais, yra veiksminga priemoné gydant ne tik pacientus, kuriems yra HP kartu su CD, bet taip pat ir pacientams, kurie CD neserga [30]. Gydymas insulinu turètų būti pasirenkamas ir tais atvejais, kada nèra galimybių atlikti plazmaferezę ar ji yra negalima. Iprasta rekomenduojama gydymo schema yra $0,1-0,3 \mathrm{VV} / \mathrm{kg} / \mathrm{val}$. trumpo veikimo insulino pastovia infuzija palaikant gliukozès kiekị kraujyje 8,3-11,1 mmol/1 ribose [19]. Duomenų, susijusių su heparino naudojimu, yra mažiau ir jie prieštaringi, nes manoma, kad didesnis lipoproteinlipazès ,atpalaidavimas“ iš endotelio ląstelių gali padidinti jos degradaciją kepenyse ir sumažinti bendrą jos kieki [31]. Todèl monoterapija heparinu nerekomenduojama ir įtraukti jị i gydymo schemą reiktų kartu su insulinu, kuris. aktyvindamas lipoproteinlipazę, tikètina apsaugo ją nuo metabolizmo $[14,32]$. Literatūros duomenimis, nèra atlikta tyrimų, kuriais remiantis būtų galima rinktis heparino skyrimo būdą. Keli publikuoti atvejai nurodo ịvairias schemas: injekcija ị veną ar po oda po $5000 \mathrm{VV}$ du kartus per dieną, pastovi intravenine infuzija nuo 420 iki $1300 \mathrm{VV}$, ar mažos molekulinès masès heparinas [33]. Mūsų atveju pacientei skirtas gydymas insulinu ir heparinas automatine švirkštimo pompa: insulinas nuo $1 \mathrm{iki} 7 \mathrm{VV} / \mathrm{val}$., heparinas $600 \mathrm{VV} / \mathrm{val}$.

Veiksmingiausia priemonè mažinant TG kiekị kraujyje yra plazmaferezè. 1978 m. pirmą kartą aprašytas HTG gydymas šiuo metodu [34]. Nors aiškių ịrodymų, kad būtų mažesnis mirštamumas taikant plazmaferezę nuo HP nėa, daugelis šaltinių ją nurodo kaip pirmo pasirinkimo gydymo metodą (III ịrodymų lygmuo, Amerikos aferezès draugija). Manoma, kad plazmafereze be TG eliminavimo iš kraujo gali turèti papildomos naudos: pašalinti su ŪP patogeneze susijusias proteazes, padidinti jautrumą insulinui ir pagerinti glikemijos kontrolę [14]. Ją rekomenduojama atlikti kiek imanoma anksčiau nuo hospitalizacijos pradžios, siekiant sumažinti TG kiekị kraujyje iki $<5,65 \mathrm{mmol} / \mathrm{l}$. Remiantis aprašytais atvejais, gali prireikti nuo vienos iki kelių procedūrų (anksti atlikta viena plazmaferezè gali sumažinti TG kiekị 65-70 proc.) [24, 35-38]. Mūsų atveju pacientei buvo atliktos dvi plazmaferezès (trečią dieną nuo hospitalizacijos 
pradžios ir per antrą parą patvirtinus HP diagnozę). Taikant kompleksines priemones mums pavyko sumažinti TG iki pageidaujamo lygio kraujyje per 48 val. TG dinamika: 20,69 mmol (2 diena) - 15,71 mmol/l (trečia diena) - 4,83 mmol/1 (ketvirta diena) (3 paveikslas). Sèkmingai koregavome ir kitus rizikos veiksnius: nuo gydymo pradžios intensyviosios terapijos skyriuje šarmų-rūgščių pusiausvyra tapo normali per 48 val., po 24 val. - ketonų šlapime pėdsakai, pasiekta tikslinè glikemija, kuri vèliau palaikyta rekomenduojamose ribose (1, 2 lentelès).

Atkreiptinas demesys, kad gydant pacientus, sergančius HP (HP kartu su CD), reiktų vengti kai kurių vaistų, kurie dažnai yra naudojami intensyviojoje terapijoje ir gali turèti itakos TG (cholesterolio) ir gliukozès kiekiui kraujyje (3 lentelè). Sedacijai neturètų būti skiriamas propofolis: riebalinè šio vaistinio preparato emulsija gali padidinti TG kieki ir bendrą cholesteroli (beje, propofolio charakteristikų santrauka nurodo, kad po 2 gydymo šiuo vaistu intensyviosios terapijos skyriuje dienų būtina tirti riebalų koncentraciją visiems pacientams). Vartojant beta adrenoblokatorius, ypač neselektyvius, galimi lipidų metabolizmo sutrikimai (šie vaistai yra vieni iš antrinès HTG rizikos veiksnių), taip pat jie negali būti vartojami esant metabolinei acidozei (sergant $\mathrm{CD}$ ). Jei reikia juos skirti, tada geriau rinktis kardioselektyvius beta adrenoreceptorių antagonistus. Esant ūmiems psichikos sutrikimams (delyrui), kurie gali būti dažni, jei alkoholis yra tarp kasos uždegimą sukèlusių rizikos veiksnių, tiek HP, tiek HP su CD metu reiktų vengti atipinių neuroleptikų (ypač olanzapino) dèl šių vaistų poveikio lipidų ir gliukozès apykaitai.

Ilgalaikiai gydymo tikslai mūsų pristatytos pacientès atveju turètų apimti antrinę pankreatito profilaktiką, užtikrinant optimalų lipidų (ypač TG) kiekị kraujyje dieta ir vaistais (teikiant pirmenybę fibratams) bei gerą CD kontrolę. Nepavykus pasiekti tikslinių lipidogramos rodiklių minètomis priemonèmis, kaip nurodo kai kurie šaltiniai, gali būti atliekamos protarpinès plazmaferezès [38]. Palaikyti TG kiekị kraujyje kuo arčiau siektinų rodiklių taip pat svarbu ir dèl to, nes nustatytas ryšys tarp HTG ir cholesteroliniu tulžies akmenų susidarymo ( 80 proc. visų tulžies akmenų), ir tai gali turèti didelę reikšmę tiek ūmaus, tiek lètinio pankreatito patogenezei [28].

\section{Išvados}

HTG yra trečia pagal dažnumą ŪP pankreatito priežastis. Išskiriamos pirminè (šeiminè) ir antrinè HTG. HP paprastai sukelia sunki HTG ( $>11,3 \mathrm{mmol} / \mathrm{l})$, kurios etiologija daugeliu atveju yra mišri (pirminè ir bent viena antrinès HTG priežastis). HP eiga gali būti sunkesnè negu kitos kilmès ŪP ir ankstyvas kompleksinių priemonių taikymas, apimantis greitą TG kiekio sumažinimą iki $<5,65 \mathrm{mmol} / \mathrm{l}$ ir antrinių HTG priežasčių kontrolę, gali padèti išvengti gyvybei grèsmingų kasos uždegimo komplikacijų. Labai svarbi yra antrinè profilaktika, skiriant ypatingą dèmesį optimaliai rizikos veiksnių kontrolei.

\section{Literatūra}

1. Singla A, Csikesz NG, Simons JP, Li YF, Ng SC, Tseng JF. et al. National hospital volume in acute pancreatitis: analysis of the Nationwide Inpatient Sample 1998-2006. HPB (Oxford) 2009; 11:391-7.

https://doi.org/10.1111/j.1477-2574.2009.00072.x

2. Yadav D, Lowenfels AB. Trends in the epidemiology of the first attack of acute pancreatitis: a systematic review. Pancreas 2006;33:323-30.

https://doi.org/10.1097/01.mpa.0000236733.31617.52

3. Cavallini G, Frulloni L, Bassi C, Gabbrielli A, CastoldiL, Costamagna G, De Rai P. et al. Prospective survey on acute pancreatitis in Italy (ProInf-AISP): results on 1005 patients. Dig Liver Dis. 2004;36(3):205-211.

https://doi.org/10.1016/j.dld.2003.11.027

4. Tenner S, Baillie J, Dewitt J, Vege SS: American College of Gastroenterology guideline: management of acute pancreatitis. Am J Gastroenterol 2013;108:1400-1415.

https://doi.org/10.1038/ajg.2013.218

5. Banks PA, Bollen TL, Dervenis C, Gooszen HG, Johnson CD, Sarr MG. et al. Classification of acute pancreatitis - 2012: revision of the Atlanta classification and definitions by international consensus. Gut 2013;62:102-111. https://doi.org/10.1136/gutjnl-2012-302779

6. Working Group IAP/APA Acute Pancreatitis Guidelines: IAP/ APA evidence-based guidelines for the management of acute pancreatitis. Pancreatology 2013;13:1-15. https://doi.org/10.1016/j.pan.2013.07.063

7. Greenberg JA, Hsu J, Marshall J, Friedrich JO, Nathens A, Coburn N. et al. Clinical practice guideline: management of acute pancreatitis. Can J Surg 2016;59:128-140.

https://doi.org/10.1503/cjs.015015

8. Gan SL, Edwards AL, Symonds CJ, Beck PL. Hypertriglyceridemia induced pancreatitis: a case-based review. World J Gastroenterol 2006;12(44):7197-7202. https://doi.org/10.3748/wjg.v12.i44.7197

9. Yadav D, Pitchumoni CS. Issues in hyperlipidemic pancreatitis. J Clin Gastroenterol 2003;36(1):54-62. https://doi.org/10.1097/00004836-200301000-00016

10. Anderson F, Mbatha SZ, Thomson SR. The early management of pancreatitis associated with hypertriglyceridemia. S Afr J Surg 2011;49:82-4.

11. Bae JH, Baek SH, Choi HS, Cho KR, Lee HL, Lee OY, Yoon BC, Hahm JS, Lee MH, Lee DH, Kee CS. Acute pancreatitis due to hypertriglyceridemia: report of 2 cases. Korean J Gas- 
troenterol 2005 Dec;46(6):475-80.

12. Fernandez R, Misra R, Nalini R. et al. Characteristics of patients with ketosis-prone diabetes (KPD) presenting with acute pancreatitis: implications for the natural history and etiology of a KPD subgroup. Endocr Pract 19: 243-251, 2013. https://doi.org/10.4158/EP12287.OR

13. Athyros VG, Giouleme OI, Nikolaidis NL. et al. Long term follow up of patients with acute hypertriglyceridemia induced pancreatitis. J Clin Gastroenterol 2002;34:472-5. https://doi.org/10.1097/00004836-200204000-00020

14. Tsuang W, Navaneethan U, Ruiz L. et al. Hypertriglyceridemic pancreatitis: presentation and management. Am J Gastroenterol 2009;104:984-91.

https://doi.org/10.1038/ajg.2009.27

15. Valdivielso P, Ramírez-Bueno A, Ewald N. Current knowledge of hypertriglyceridemic pancreatitis. Eur J Intern Med 2014 Oct;25(8):689-94.

https://doi.org/10.1016/j.ejim.2014.08.008

16. Carr RA, Rejowski BJ, Cote GA, Pitt HA, Zyromski NJ. Systematic review of hypertriglyceridemia induced acute pancreatitis: A more virulent etiology? Pancreatology 2016 Jul-Aug;16(4):469-76.

https://doi.org/10.1016/j.pan.2016.02.011

17. Anderson F, Thomson SR, Clarke DL, Buccimazza I. Dyslipidaemic pancreatitis clinical assessment and analysis of disease severity and outcomes. Pancreatol Off J Int Assoc Pancreatol 2009;9:252-7.

https://doi.org/10.1159/000212091

18. Banks PA, Freeman ML. Practice guidelines in acute pancreatitis. Am J Gastroenterol 2006;101:2379-400.

https://doi.org/10.1111/j.1572-0241.2006.00856.x

19. Chaudhary A, Iqbal U, Anwar H, Siddiqui HU, Alvi M. Acute pancreatitis secondary to severe hypertriglyceridemia: management of severe hypertriglyceridemia in emergency setting. Gastroenterology Res 2017 Jun;10(3):190-192.

https://doi.org/10.14740/gr762e

20. Balachandra S, Virlos IT, King NK. et al. Hyperlipidaemia and outcome in acute pancreatitis. Int J Clin Pract 2006;60:156-9. https://doi.org/10.1111/j.1742-1241.2005.00645.x

21. Albai O, Roman D, Frandes M. Hypertriglyceridemia, an important and independent risk factor for acute pancreatitis in patients with type 2 diabetes mellitus. Ther Clin Risk Manag. 2017 Apr 13;13:515-522. https://doi.org/10.2147/TCRM.S134560

22. Minhas J, Thakkar D, Dargin J. Hypertriglyceridemia induced acute pancreatitis. J Emerg Med 2017 Mar;52(3):89-90. https://doi.org/10.1016/j.jemermed.2016.10.018

23. Fujishiro M, Horita A, Nakagawara H, Mawatari T, Kishigami Y, Tominaga Y, Moriyama M, Ishihara H. Severe hypertriglyceridemia possibly masked acute pancreatitis and led to a difficult diagnosis in an obese patient with ketoacidosis onset type 2 diabetes. Intern Med 2017 Oct 1;56(19):2611-2616.

https://doi.org/10.2169/internalmedicine.8474-16

24. Stefanutti C, Labbadia G, Morozzi C. Severe hypertriglyceridemia related acute pancreatitis. Ther Apher Dial 2013 Apr;17(2):130-7. https://doi.org/10.1111/1744-9987.12008

25. Havel RJ. Pathogenesis, differentiation and management of hypertriglyceridemia. Adv Intern Med 1969;15:117-54.

26. Saharia P, Margolis S, Zuidema GD, Cameron JL. Acute pancreatitis with hyperlipemia: studies with an isolated perfused canine pancreas. Surgery 1977;82:60-7.

27. Chang YT, Chang MC, Su TC. et al. Association of cystic fibrosis transmembrane conductance regulator (CFTR) mutation/ variant/haplotype and tumor necrosis factor (TNF) promoter polymorphism in hyperlipidemic pancreatitis. Clin Chem 2008;54:131-8.

https://doi.org/10.1373/clinchem.2007.093492

28. Westphal SA. The occurrence of diabetic ketoacidosis in non-insulin-dependent diabetes and newly diagnosed diabetic adults. Am J Med. 1996;101(1):19-24.

https://doi.org/10.1016/S0002-9343(96)00076-9

29. Ewald N, Hardt PD, Kloer HU. Severe hypertriglyceridemia and pancreatitis: presentation and management. Curr Opin Lipidol 2009;20:497e504.

30. Mikhail N, Trivedi K, Page C. et al. Treatment of severe hypertriglyceridemia in nondiabetic patients with insulin. Am J Emerg Med 2005;23:415-7.

https://doi.org/10.1016/j.ajem.2005.02.036

31. Nasstrom B, Olivecrona G, Olivecrona T. et al. Lipoprotein lipase during continuous heparin infusion: tissue stores become partially depleted. J Lab Clin Med 2001;138:206-13.

https://doi.org/10.1067/mlc.2001.117666

32. Berglund L, Brunzell JD, Goldberg AC. et al. Evaluation and treatment of hypertriglyceridemia: an Endocrine Society clinical practice guideline. J Clin Endocrinol Metab 2012;97(9):2969-2989.

https://doi.org/10.1210/jc.2011-3213

33. Cole RP. Heparin treatment for severe hypertriglyceridemia in diabetic ketoacidosis. Arch Intern Med. 2009 Aug 10;169(15):1439-41.

https://doi.org/10.1001/archinternmed.2009.221

34. Betteridge DJ, Bakowski M, Taylor KG. et al. Treatment of severe diabetic hypertriglyceridaemia by plasma exchange. Lancet 1978;1:1368.

https://doi.org/10.1016/S0140-6736(78)92450-9

35. Szczepiorkowski ZM,Winters JL, Bandarenko N. et al. Guidelines on the use of therapeutic apheresis in clinical practice evidence based approach from the Apheresis Applications Committee of the American Society for Apheresis. J Clin Apher 2010;25:83-177.

https://doi.org/10.1002/jca.20240 
36. Kohli RS, Bleibel W, Shetty A, Dhanjal U. Plasmapheresis in the treatment of hypertriglyceridemic pancreatitis with ARDS. Dig Dis Sci 2006;51(12):2287-2291. https://doi.org/10.1007/s10620-006-9315-x

37. Kadikoylu G, Yavasoglu I, Bolaman Z. Plasma exchange in severe hypertriglyceridemia a clinical study. Transfus Apher Sci 2006;34(3):253-257.

https://doi.org/10.1016/j.transci.2005.11.009

38. Piolot A, Nadler F, Cavallero E, Coquard JL, Jacotot B. Prevention of recurrent acute pancreatitis in patients with severe hypertriglyceridemia: value of regular plasmapheresis. Pancreas 1996;13(1):96-99.

https://doi.org/10.1097/00006676-199607000-00013

\section{CLINICAL CASE: HYPERLIPIDEMIC \\ PANCREATITIS}

\section{A. Gintautas, T. Janušonis, R. Paškevičiūtė}

Key words: hyperlipidaemia, pancreatitis, diabetes mellitus, diabetic ketoacidosis, plasmapheresis.

Summary

Hyperlipidemic pancreatitis (HP) is diagnosed when there is very high level of blood triglycerides (TG) and there are no other possible causes of the acute pancreatitis (AP). We present a clinical case of HP which was diagnosed together with diabetic ketoacidosis (DKA) and type 2 diabetes mellitus (DM) in 39 years old woman. Diagnosis of DM was issed for the first time, i.e. DKA was the initial manifestation of diabetes mellitus. The performed test confirmed diagnosis of the AP, and also the severe hypertriglyceridemia (HTG) (20.69 mmol/l) was found. With the usual therapy of the AP and the complex therapy of the HP (plasmapheresis and the continuous insulin and heparin infusion we achieved a decrease in blood TG level to the optimal one in two days. The general patient's status was stable during the stay in the intensive care unit, however there were infectious complications. The patient was discharged after 23 days of treatment in the hospital (the further care plan under specialists' control was recommended and the importance or risk factors management was highlighted).

Correspondence to: armantasg@gmail.com

Gauta 2017-11-06 